\title{
Pengembangan Kepercayaan Diri Mahasiswa dalam Berbahasa Inggris melalui Teknik Writing debagai Pendukung Capaian Pembelajaran
}

\author{
Occe Luciana \\ STIE Wibawa Karta Raharja, Indonesia \\ Email: lucianaocce@gmail.com
}

\begin{abstract}
Abstrak: Krisis kepercayaan diri adalah salah satu persoalan mahasiswa dalam berbahasa. Saat karantina covid-19 ini, dimana perkuliahan dilakukan secara daring, mata kuliah bahasa Inggrispun dilaksanakan online. Seperti kebetulan ketika perkuliahan tatap muka dianggap sulit karena harus berkomunikasi verbal in English, mahasiswa serta merta harus belajar online di google classroom. Studi ini bertujuan untuk melihat apakah terdapat peningkatan kepercayaan diri mahasiswa dalam berbahasa Inggris ketika perkuliahan dilakukan online dalam bentuk chat/writing . Dan untuk menganalisa apakah perkuliahan tersebut memenuhi capaian pembelajaran ataukah tidak. Kualitatif adalah metode yang penulis gunakan yaitu
\end{abstract}

\author{
Tersedia Online di \\ http://journal.unublitar.ac.id/pendidikan \\ /index.php/Riset_Konseptual \\ Sejarah Artikel \\ Diterima pada : 08-07-2020 \\ Disetuji pada : 30-07-2020 \\ Dipublikasikan pada : 31-07-2020

\section{Kata Kunci:} \\ Percaya diri, chat/writing, capaian \\ pembelajaran \\ DOI: \\ http://doi.org/10.28926/riset_konseptual.v4i3.2 \\ 68
}

mendeskripsikan analisa dari kuesioner yang disebar online menggunakan google form. Meski jawaban hasil kuesioner menunjukkan 38,2\% saja menyatakan perkuliahan online lebih mudah dibanding offline, namun penulis melihat hampir semua mahasiswa mampu mencurahkan pemikirannya dalam forum chat yang menyebabkan peningkatan kepercayaan diri mereka. Ini dibuktikan sebanyak $61,8 \%$ mahasiswa memiliki peningkatan kepercayaan diri berbahasa Inggris ketika belajar, berdiskusi, bertanya materi perkuliahan melalui chat di forum google classroom.

\section{PENDAHULUAN}

Pendidikan menurut kamus besar bahasa Indonesia (KBBI) adalah proses pengubahan sikap dan tata laku seseorang atau kelompok orang dalam usaha mendewasakan manusia melalui upaya pengajaran dan pelatihan.

Kaitannya dengan bahasa Inggris sebagai mata kuliah yang penulis ampu di kampus, pendidikan bahasa Inggris pun berproses demikian yaitu sebuah pengajaran dan pelatihan untuk mengubah sikap dan tata laku seseorang atau kelompok dalam mendewasakan manusia. Terlebih di era globalisasi ini bahasa Inggris begitu perlu untuk dipelajari. Mulai dari persyaratan kuliah di luar negeri, mendapatkan beasiswa, persyaratan melamar pekerjaan, hingga akses media internet yang saat ini sedang boom karena karantina covid-19, mayoritas melibatkan bahasa Inggris dalam prosedurnya. Maka tidak diragukan lagi pemahaman komunikasi menggunakan bahasa Inggris sangatlah dibutuhkan.

Pembelajaran bahasa Inggris dikampus baik dilaksanakan secara off-line maupun on-line diharapkan dapat mengubah sikap dan tata laku mahasiswa dari tidak mengerti menjadi mengerti, dari tidak tahu menjadi tahu, dan dari tidak percaya diri menjadi percaya diri, dalam hal ini berani menjawab pertanyaan secara spontan, percaya diri dalam mengutarakan alasan/pendapat, mantap hati ketika mengemukakan sebuah argumen.

Namun kenyataannya, pembelajaran bahasa Inggris di kampus belumlah membuahkan hasil yang memuaskan dalam kepercayaan diri mahasiswa untuk berkomunikasi bahasa Inggris secara verbal, meski penilaian orang kepada mahasiswa yang belajar bahasa Inggris adalah mereka bisa berbicara menggunakan 
bahasa Inggris. Kenyataan ini membuat mayoritas mahasiswa merasa bahasa Inggris adalah benar-benar bahasa asing yang sulit digunakan. Sebagian mahasiswa menghindar dari pertanyaan jika itu tiba gilirannya.

Salah satu upaya membantu mahasiswa meningkatkan keberanian/percaya diri dalam berbahasa Inggris, penulis memilih teknik writing dalam pertimbangan penelitiannya. Ini selaras dengan pendapat Dr. Joseph dalam TED Talk - The Skill of Self-Confidence https://www.ignitiaoffice.com/ted-talk-skill-self-confidence/ bahwa kepercayaan diri adalah, 'kemampuan untuk memercayai keterampilan Anda untuk menyelesaikan tugas apa pun, tidak masalah apa pun risikonya, tidak masalah kesulitannya, dan tidak masalah hambatan apapun.'

Merujuk pendapat Joseph tersebut di atas, penulis mengaitkannya dengan kepercayaan diri yang diperoleh mahasiswa saat belajar online. Ketika mahasiswa berkemampuan untuk mengetahui keterampilan dirinya menyimak dan mengomentari perkuliahan bahasa Inggris maka, kepercayaan diri dengan sendirinya muncul. Dengan online dimana perkuliahan digelar dalam forum diskusi menggunakan tulisan (chat), memberikan kesempatan kepada mahasiswa untuk memikirkan terlebih dahulu apa yang akan disampaikannya. Juga menyediakan kesempatan menterjemahkan ke dalam bahasa Inggris sambil menunggu komentar dari peserta yang lain.

Tidak hanya searah dengan pendapat Joseph, namun writing juga telah signifikansi dengan kebiasaan kita di masa pandemi ini yaitu berakses melalui internet, baik di media sosial ataupun google classroom yang sebagian besar menggunakan writing (tulisan) dalam berkomunikasi.

Dengan dilaksanakannya eksperimen ini, Penulis berharap hal tersebut dapat bermanfaat tidak hanya bagi pribadi penulis namun juga bagi teman-teman peneliti sebagai salah satu rujukan studinya, dan bagi para pendidik lainnya.

Berdasarkan temuan seperti disebutkan diatas maka, dalam studi ini penulis mengambil judul Pengembangan kepercayaan diri mahasiswa dalam berbahasa Inggris melalui teknik writing sebagai pendukung capaian pembelajaran.

\section{METODE}

Observasi ini dilakukan selama kurang lebih 7 pekan terhadap 46 mahasiswa semester 2 dari program studi Akuntansi dan Manajemen di STIE WIKARA. Setiap pertemuan dalam forum chat google classroom penulis membuka terlebih dahulu dengan greeting ringan, membalas respons mahasiswa, menanyakan yang belum hadir kemudian membagikan link absen. Selanjutnya barulah mengintroduksi materi perkuliahan.

Adapun diskusi digelar setelah penulis memposting artikel atau video terkait topik perkuliahan. Sebagian besar langsung merespons dengan komentar-komentar pendek, sebagian lagi ada yang masih membaca dan menyimak video, sebagian sisanya tidak ada tanggapan apa-apa. Semuanya mengalir dalam chat bahasa Inggris sesuai kemampuan mereka.

Begitupun ketika penulis membagikan google form link kepada mahasiswa untuk instrumen penelitian berupa kuesioner, mereka langsung memberikan tanggapannya. Dan yang masuk sebanyak 34 responden.

\section{HASIL DAN PEMBAHASAN}

Berikut adalah analisa dari 34 tanggapan yang masuk dari 46 populasi:

- Meskipun hanya 38,2\% menyatakan belajar bahasa Inggris online di google classroom lebih mudah dibanding belajar offline dikelas, namun sebanyak $52,9 \%$ merasa senang belajar bahasa Inggris di google classroom. 
7. Apakah Anda senang belajar bahasa Inggris di google classroom?

34 tanggapan

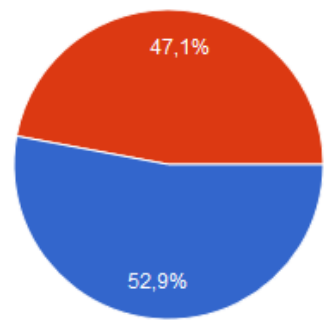

Ya

9. Apakah belajar bahasa Inggris melalui chat di forum google classroom lebih mudah daripada speaking dikelas offline/online?

34 tanggapan

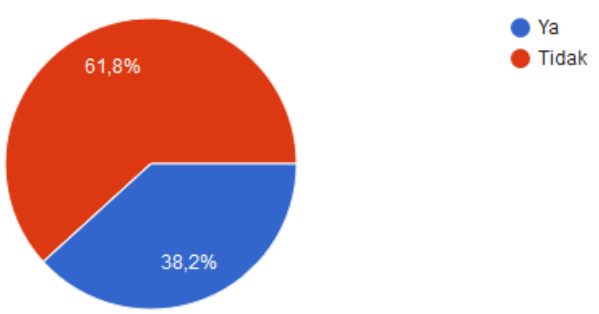

- Sebanyak $61,8 \%$ menyatakan ada peningkatan kepercayaan diri dalam berbahasa Inggris ketika belajar/berdiskusi/bertanya tentang materi perkuliahan melalui chat di google classroom. Pernyataan ini diperkuat dengan sebanyak $55,5 \%$ dari pernyataan mahasiswa menyatakan bahwa bahasa Inggris writing lebih mudah daripada speaking.

10. Apakah ada peningkatan kepercayaan diri dalam berbahasa Inggris ketika Anda belajar/berdiskusi/bertanya tentang materi perkuliahan melalui chat di forum google classroom?

34 tanggapan

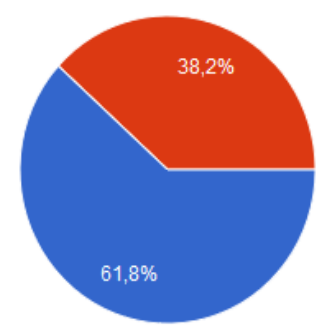




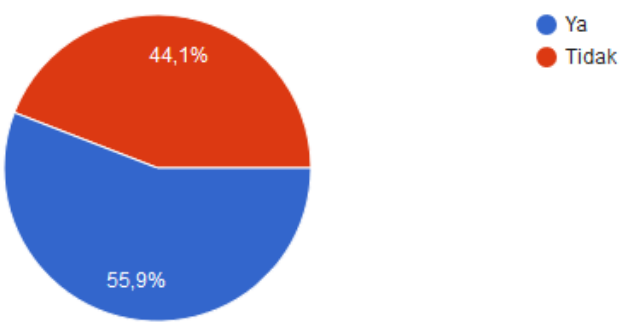

Jika kita berpijak pada hasil jawaban kuesioner dapat diambil kesimpulan bahwa krisis kepercayaan diri dapat terkikis dengan tindakan lain yang membuat mahasiswa merasa memiliki kemampuan di bidang tersebut, dalam hal ini adalah metode writing atau menyampaikan pendapat melalui tulisan. Melalui tulisan (writing), mahasiswa dapat mengekspresikan idenya tanpa khawatir pikir-pikir terlebih dahulu mencari kosa kata bahasa Inggris dalam benaknya. Mereka hanya menuliskan apa yang akan disampaikan lalu menterjemahkannya ke dalam bahasa Inggris melalui google translate. Maka tidak heran jika hanya $38,2 \%$ saja mahasiswa yang menyatakan bahwa belajar bahasa Inggris online lebih mudah dari belajar offline. Ini membuktikan mayoritas mahasiswa merasa tidak lebih mudah ketika belajar bahasa Inggris online. Bisa dipahami jika memang setiap akan memposting harus translate dulu ke dalam bahasa Inggris.

\section{Kepercayaan Diri}

Definisi kepercayaan diri yaitu "Percaya diri adalah sikap positif seorang individu yang mampu untuk mengembangkan penilaian positif baik terhadap diri sendiri maupun terhadap lingkungan/situasi yang dihadapinya."

https://www.percayadiri.com:2008

Claudia Pesce dalam 7 Sure-fire Ways to Boost Student Confidence mengatakan bahwa penting bagi mahasiswa untuk merasa percaya diri, karena jika tidak, mereka tidak belajar secepat atau mendapatkan kefasihan yang mereka butuhkan. Mahasiswa yang kurang percaya diri sering mengeluh atau mengatakan hal-hal seperti, "Saya tidak bisa melakukannya"; "Saya tidak tahu bagaimana mengatakannya".

Claudia juga mengatakan dalam tulisannya tentang salah satu cara meningkatkan kepercayaan diri adalah dengan diberikan pujian ketika mahasiswa selesai melengkapi tugas, dan mahasiswa juga akan merasa senang jika diberikan koreksi seperlunya atas pekerjaannya.

Menurut Dr. Joseph, kepercayaan diri adalah keterampilan. Tanpa keterampilan ini, seorang pemain tidak akan pernah bisa menjadi hebat. Ini karena seperti yang didefinisikan oleh Dr. Joseph, kepercayaan diri adalah, 'kemampuan untuk memercayai keterampilan Anda untuk menyelesaikan tugas apa pun, tidak masalah apa pun risikonya, tidak masalah kesulitannya, dan tidak masalah hambatan apapun.' TED Talk - The Skill of Self-Confidence https://www.ignitiaoffice.com/ted-talk-skill-selfconfidence/

Merujuk pendapat Joseph tersebut di atas, penulis mengaitkannya dengan kepercayaan diri yang diperoleh mahasiswa saat belajar online. Ketika mahasiswa berkemampuan untuk mengetahui keterampilan dirinya menyimak dan mengomentari perkuliahan bahasa Inggris maka, kepercayaan diri dengan sendirinya muncul. Dengan online dimana perkuliahan digelar dalam forum diskusi menggunakan tulisan (chat), memberikan kesempatan kepada mahasiswa untuk memikirkan terlebih dahulu apa yang akan disampaikannya. Juga menyediakan kesempatan menterjemahkan ke dalam bahasa Inggris sambil menunggu komentar dari peserta yang lain. 


\section{Teknik Writing}

Menurut MD Satriani (2012) dalam eprints.uny.ac.id menjelaskan teori writing menurut para ahli yaitu diantaranya menurut Tarigan (1985: 5) menulis adalah keterampilan produktif, untuk menulis komunikasi secara tidak langsung dan sifat karakter yang sangat berbeda dari yang diungkapkan dengan berbicara langsung, oleh karena itu menulis termasuk sebuah keahlian. Harmer (2001: 79) mengatakan bahwa menulis adalah suatu bentuk komunikasi untuk menyampaikan perasaan atau mengungkapkan perasaan melalui bentuk tertulis. Ini berarti bahwa menulis adalah keterampilan produktif yang mengungkapkan perasaan melalui komunikasi tertulis.

\section{Jenis-jenis Writing}

Masih menurut MD Satriani (2012) dalam eprints.uny.ac.id Brown (2001: 343346) mengatakan ada lima kategori utama dalam writing yaitu: Imitative or Writing Down, Intensive or Controlled, Self- Writing, Display Writing, dan Real Writing.

Imitative adalah tipe Writing dengan menuliskan huruf, kata, atau kalimat yang disebutkan, misalnya dari sebuah dictation (dikte). Jenis Intensive or Controlled adalah Writing yang dibuat oleh mahasiswa setelah sebelumnya dosen memberikan sebuah paragraf untuk dibuat sebuah kalimat baru dengan menampilkan kemampuan dalam tata bahasa.

Adapun Self-Writing dimaksudkan bahwa Writing tipe ini adalah mahasiswa menuliskan apa yang ada di dalam pemikiran mereka, seperti menulis ketika perkuliahan, menulis buku harian, dan sejenisnya.

Sedangkan Display Writing dan Real Writing adalah tipe-tipe Writing semacam menulis essay, laporan akademik, dan semacamnya.

\section{Capaian Pembelajaran}

Definisi Capaian Pembelajaran menurut Ichsanbah dalam blog tahun 2019 https://ichsanbah.blogspot.com/2018/12/capaian-pembelajaran.html

Capaian Pembelajaran dapat diartikan sebagai pernyataan dari suatu tujuan pendidikan berupa penjelasan tentang sesuatu yang diharapkan untuk diketahui, dimengerti, dan peserta didik dapat mengaplikasikannya setelah selesai pembelajaran. Capaian Pembelajaran sering disebut juga 'kompetensi' meski dari segi cakupan pendekatan mengandung arti yang berbeda.

Allan dalam Butcher (2006) mengatakan bahwa educational intent, banyak dijelaskan dalam beberapa terminology, diantaranya yaitu: learning outcomes; teaching objectives; competencies; behavioural objectives; goals; dan aims.

Butcher (2006) mengatakan, 'aims' adalah pernyataan sebuah tujuan pendidikan secara umum dan luas yang menerangkan informasi tentang tujuan pembelajaran kepada siswa. Sedangkan Capaian Pembelajaran (learning outcomes) lebih fokus pada sesuatu yang diiharapkan siswa dapat melakukannya pada akhir pembelajaran. Sementara 'objectives' lingkupnya meliputi belajar mengajar dan ini seringkali digunakan dalam proses asesmen.

Adapun Capaian Pembelajaran yang diharapkan dalam perkuliahan di 7 pekan tersebut adalah mahasiswa mampu mengutarakan pendapat, berkomentar, dan berkomunikasi dengan kalimatnya sendiri.

\section{KESIMPULAN}

Dari paparan pembahasan dan hasil jawaban kuesioner di atas dapat ditarik kesimpulan bahwa kepercayaan diri mahasiswa dalam berbahasa dapat dikembangkan atau ditingkatkan melalui teknik writing. Tentu tidak seluruh tipe writing yang diterapkan namun hanya satu saja yaitu Self-Writing. Mahasiswa menuliskan apa yang ada di dalam pemikirannya, memberikan komentar dari apa yang dibaca atau dilihatnya dalam sebuah video. Juga bertanya hal yang kurang dipahami, yang dapat dijawab oleh temannya atau oleh dosen pengampunya. Semuanya bergulir dalam tulisan (chat) bahasa Inggris dalam forum google classroom. Ketika akan memposting sebuah komentar, kerap mahasiswa menggunakan google translate untuk memastikan kalimatnya sudah dalam bahasa Inggris. Meski hasil terjemahan tidak selalu sesuai 
dengan yang dipikirkan namun itu telah membuat mereka merasa dimudahkan untuk berkomunikasi in English. Berawal dari merasa mudah inilah kepercayaan diri dalam berbahasa akhirnya berkembang. Aktif dalam berkomunikasi tulisan dalam forum menjadi hal yang ramai dalam perkuliahan online tersebut.

Kaitannya dengan Capaian Pembelajaran, teknik writing (dalam hal ini selfwriting) signifikansi dengan pengembangan kepercayaan diri dalam berbahasa. Mahasiswa yang percaya diri berkomunikasi tulisan telah berhasil mengutarakan pemikirannya dengan kata-katanya sendiri.

\section{DAFTAR RUJUKAN}

Apriliani, Dita. (2015). Peningkatan percaya diri melalui model pembelajaran kooperatif tipe: think and share pada pembelajaran IPS siswa kelas V SD Negeri Serang Kulon Progo. Skripsi. Univ. Yogyakarta.

Arifin, Syamsul. (2018). Desain kurikulum Pendidikan Tinggi sesuai dengan KKNI dan SN-Dikti di era industri 4.0. Kemenristekdikti.

Dicky Pradana, Irvan. (2016). Kepercayaan diri dalam penyampaian pendapat pada mahasiswa awal Universitas Muhammadiyah Surakarta. Naskah Publikasi. Univ. Muhammadiyah Surakarta.

Perpres No. 8 tahun 2012. KKNI.

Satriani, MD. (2012). https://www.percayadiri.com:2008

eprints.uny.ac.id.

TED Talk - The Skill of Self-Confidence https://www.ignitiaoffice.com/ted-talk-skill-selfconfidence/

https://busyteacher.org/2971-how-to-effectively-teach-english-writing-skills.html

https://forum.english.best/t/in-today-s-world-to-speak-well-is-more-important-than-towrite-well-agree-or-di/35640

https://ichsanbah.blogspot.com/2018/12/capaian-pembelajaran.html

https://kbbi.web.id

https://zhaminang.wordpress.com/2013/05/17/definisi-menulis-menurut-para-ahli/ 